\title{
PREHISTORIC ORNAMENTATION: \\ POSSIBLE DIRECTIONS IN RESEARCH AND ASPECTS FOR INTERPRETATION AS SUGGESTED BY ANALYSIS OF TRIPOLYE-CUCUTENI POTTERY
}

\begin{abstract}
Palaguta I. V. 2016. Prehistoric ornamentation: possible directions in research and aspects for interpretation as suggested by analysis of Tripolye-Cucuteni pottery. Sprawozdania Archeologiczne 68, 65-80.

The paper proposes an interpretation of ornamental patterns in Tripolye-Cucuteni pottery. In the past decades, abstract and geometric ornamental motifs have often been viewed quite subjectively as images of the 'moonfaced Goddess', the 'world egg', 'shells', etc. The meaning of the ornamentation has been reconstructed on the basis of various ethnographic analogies, usually rather distant from the material under study.

Within the framework of the structural-semiotic approach, the ornamentation has been analysed as a sign system or proto-writing where each element or motif is supposed to have a particular meaning. However, careful study of the dynamics inherent in the development of ornamental patterns shows that such interpretation cannot really be substantiated. Most signs seem to have been elements of technical design. The patterns were mostly created by dividing ornamented areas and not by building whole sequences of signs as it is done in texts. What was meaningful was the ornament itself as an integrated whole, not its elements.

Ethnographic evidence shows that interpretation of identical motifs may vary considerably even within the same society. This has been confirmed by the author's study of variation in the Tripolye patterns, which seem to have no unambiguous meaning. The main areas of future research lie in paleo-ethnological and paleo-cultural studies, where ornamental patterns are regarded as specific markers which reflect changes in the ethnic composition and social structure of prehistoric communities, and which provide information about interactions between different human groups.
\end{abstract}

Keywords: ornamentation, Tripolye-Cucuteni culture, ornamental elements and motifs, semantics Received: 16.04.2015; Revised: 01.12.2015; Accepted: 21.05.2016

${ }^{*}$ St. Petersburg Stieglitz State Academy of Art and Design, Solyanoy pereulok 13, 191028 St. Petersburg, Russian Federation; ipalaguta@yandex.ru 
Semantics of ornamental patterns and their interpretation prove to be a very attractive area of research; at the same time, it is an area most open to criticism. The semantic approach centres around the meaning of the patterns and around the "correspondences between abstract or geometric forms of the ornamentation and realistic images of objects" (Kozhin 1981, 133-134). However, this is precisely where researchers' subjectivity is the most visible and where their interpretations of the same patterns can be diametrically opposed. Nevertheless, a whole area of study has developed where the prehistoric patterns are viewed as symbolic systems or symbol sets amenable to reading like texts.

The scholarly interest is related to the materials of the Tripolye-Cucuteni culture, which covered extensive areas of south-eastern Europe from the Carpathians to the Dnieper in the Neolithic and the Copper Ages, from the mid-5th millennium to the early 3rd millennium BC. The Tripolye-Cucuteni culture stood out among other European archaeological cultures of the same period because of the variety and complexity of ornamental motifs on its pottery. This paper aims to consider the assumptions which underlie various interpretations of the Tripolye-Cucuteni ornamentation, to assess the probability of detecting its meaning, and to outline possible directions of further research.

\section{LOOKING FOR THE SEMANTIC BASIS OF THE TRIPOLYE-CUCUTENI ORNAMENTATION: THE CENTENARY OF RESEARCH}

The first attempts at reading the Tripolye ornamentation as pictograms or a 'prototype of some kind of ornamental alphabet' were made at the turn of the 19th and 2oth centuries, just after the first Tripolye sites in the Ukraine were discovered (Linnichenko, Khvoyka 1901, 199-202; Bolsunovsky 1908). The attempts were ineffective except for positing a possibility of such a reading. Subsequent publications, based on the assumption that the Tripolye patterns did represent a system of readable symbols, provided their interpretation.

One of the first proposals of that kind was K.V. Bolsunovsky's paper concerning snakelike motifs on Tripolye pottery (Bolsunovsky 1905). The author used the comparative method that dominated in ethnography at that time (e.g. in J.J. Frazer's study of ancient religions). It involved all available analogies, even those with rituals or beliefs recorded in Europe in the late 19th century, according to their formal similarity. Bolsunovsky, drawing on Lithuanian and Slavic ethnography and toponymy, interpreted the Tripolye patterns as 'snakes' or a 'home deity - alive fetish', since he was convinced that 'the Tripolye culture, which belonged ethnologically to ancient Aryans, was in fact proto-Slavic' (Bolsunovsky 1905, 13). Although there was no sufficient evidence of continuity between the Tripolye culture and the Slavs, the same approach was adopted by numerous researches at that time, e.g. by Gustaf Kossinna, the famous German migrationist (Kleyn 2000). Fifty years later, it provided the basis for the interpretation proposed by USSR academician Boris 
Rybakov, who made no attempt to identify the origin of the Tripolye-Cucuteni culture, its relationship with the Indo-Europeans or its ties with successive cultures.

In the 1930s, B.L. Bogaevsky used a number of ethnographic and historical analogies to interpret some elements of the Tripolye ornamentation as bearing external similarity to cowry shells. Although he admitted that 'in painted Tripolye pottery, the function of seashell motifs ... was never quite clear,' he stated that the motifs 'represent retellings of real schemes whose true significance, prevalent in China and Crete, is distant and generally forgotten' (Bogaevsky 1931, 69). In his view, elliptical patterns on the pottery should mostly be identified as seashell motifs. Bogaevsky was probably the first researcher to use the term 'face' when describing some of the patterns, due to their similarity to an outline of a face with two dots for the eyes (Bogaevsky 1931, 74, fig. 51). He was no exception among researches at that time, as similar parallels between ornamentation typical of European and Eastern Asian agricultural cultures were drawn by German archaeologist H. Schmidt, who investigated the eponymous Cucuteni site in Romania in 1909-1910. Schmidt explained the parallels with the theory of migrations (Schmidt 1924).

It should be noted that Bogaevsky considered the formation of the shell-like figures as a result of 'the gradual decline of helical tape'; namely, when 'transformation of the helical tape into an oval forming an independent element of the ornamentation was almost finished, the oval was rethought' as a 'conchoidal pattern' (Bogaevsky 1931, 82). It was important, firstly, because Bogaevsky showed that the meaning of the patterns may have been rethought by their makers and thus it could be polysemous, and, secondly, because the visual examination was complemented with typological observations, though the final reading was based on unproven external formal analogies.

In the 1920 and the1930s, the typology of the patterns and their transformation became the subject of special study (Chikalenko 1926; Čikalenko 1927; Dintses 1929; Kandyba 1935; Kandyba 1936; Krichevsky 1949). However, the research was not continued after World War II, for various reasons; from among the scholars mentioned above, Oleg Kandyba died in in the Sachsenhausen concentration camp in 1944, Eugene Krichevsky died during the blockade of Leningrad, Levko Chikalenko emigrated to the USA, and Leo Dintses shifted his interest to folk art and art history.

In the 1960 s and the 1970s, interpretation of the Neolithic and Copper Age ornamental patterns was dominated by ideas proposed by Boris Rybakov and Maria Gimbutas. Although the researchers worked in two different countries, the USSR and the USA respectively, they formulated similar theories and based them likewise not on thorough analysis of the material, but on their own subjective notions.

In his text from 1963, Rybakov briefly but tellingly presented the premises of analysing the Tripolye ornamentation. The basis of his theoretical framework was as follows:

1) 'The meaning of the painted ceramics was essentially linked with the psychology of early farmers whose living conditions depended directly and completely on the generosity of the skies, primarily on rain.' 
2) 'The ornamentation of the vessels intended for storage of grain, flour, water or milk was related to the Tripolye system of agrarian magic rituals.'

3) 'Determination of the possible rate of cosmological generalizations must be based on the common Indo-European lexis,' dating from the 4th-the 3 rd millennia BC.

4) Accordingly, it is 'necessary to use the archaic layers of the Indo-European folklore', when interpreting the ornamental patterns (Rybakov 1964, 24).

Premises 1 and 2 point to a speculative approach with the $a$ priori assumption that the decorative patterns reflected agrarian magic rituals. Premises 3 and 4 resulted from Rybakov's position on the autochthonic development of the Slavs in Eastern Europe in the Neolithic and the Bronze Ages (see Rybakov 1981). In the 196os, autochthonism of that kind was linked to political tasks of the Soviet state: 'cultivating the patriotic pride in native culture, backing up the current international relations with ancient precedents' and 'upholding the principle of "historic rights" to the territory' (Kleyn 1993, 32, 37). In his autochthonism, Rybakov also referred to elements of the stadial theory popular in Soviet Marxist archaeology of the 1930 s but seemingly forgotten in the 1960s. For example, he explained changes that had occurred in the ornamental patterns during the transition from the Neolithic to the Bronze Ages with matriarchy being supplanted by the patriarchal society (Rybakov 1964, 24-25). He accounted in that way for 'agricultural' symbols in the Tripolye patterns: 'ideograms of water', 'celestial waters', 'seeds', 'air space filled with bright wide spirals, their core taking the form of solar signs', 'motifs of the female breast', etc. (Rybakov 1964, 24). It should be noted that Rybakov was fully aware of the subjective nature of such 'deductive' constructions (Rybakov 1981, 174-175), but he saw no reason to discard them.

Maria Gimbutas' ideas seem a mirror reflection of Rybakov's statements, but they were based on other ethno-historical interpretation. In Gimbutas' view, the Indo-European Kurgan culture destroyed the Pre-Indo-European matriarchal civilization of the Great Goddess. In her theories, Gimbutas synthesized the 'threat from the East' mythologeme with the ideology of feminism. Apparently influenced by her Soviet colleague, she viewed e.g. the pattern of an oval conjoined with a wavy line as a 'world egg' sailing 'the waters of the primordial chaos', while the pattern of spirals seemed to her to represent the face of the Bird-Goddess (Gimbutas 1974, 95, 101-107, 112-114, 166-168 et al.). Because Gimbutas had a considerable standing in archaeology, she was criticised for the subjective nature of her reconstructions only after her death in 1994 (Bailey 1994, 323; Meskell 1995; Chapman 1999, 104). It is worth noting that Gimbutas' ideas were also linked with Carl Gustav Jung's theory of archetypes which postulated a universal symbolic system as the basis for each human culture. The universalistic assumption provided Gimbutas with a reason to frame the theory of the universal prehistoric religion of Mother Goddess and thus to account not only for the Neolithic ornamentation but also for sculpture (see Hutton 1997; Lesure 2011).

Rybakov's and Gimbutas' texts were followed by numerous publications. Their authors considered the ornamental patterns of the Tripolye-Cucuteni and other European Neolithic cultures from similar perspective (Telegin 1994; Burdo 1999; Tsvek 2004, etc.). Most 

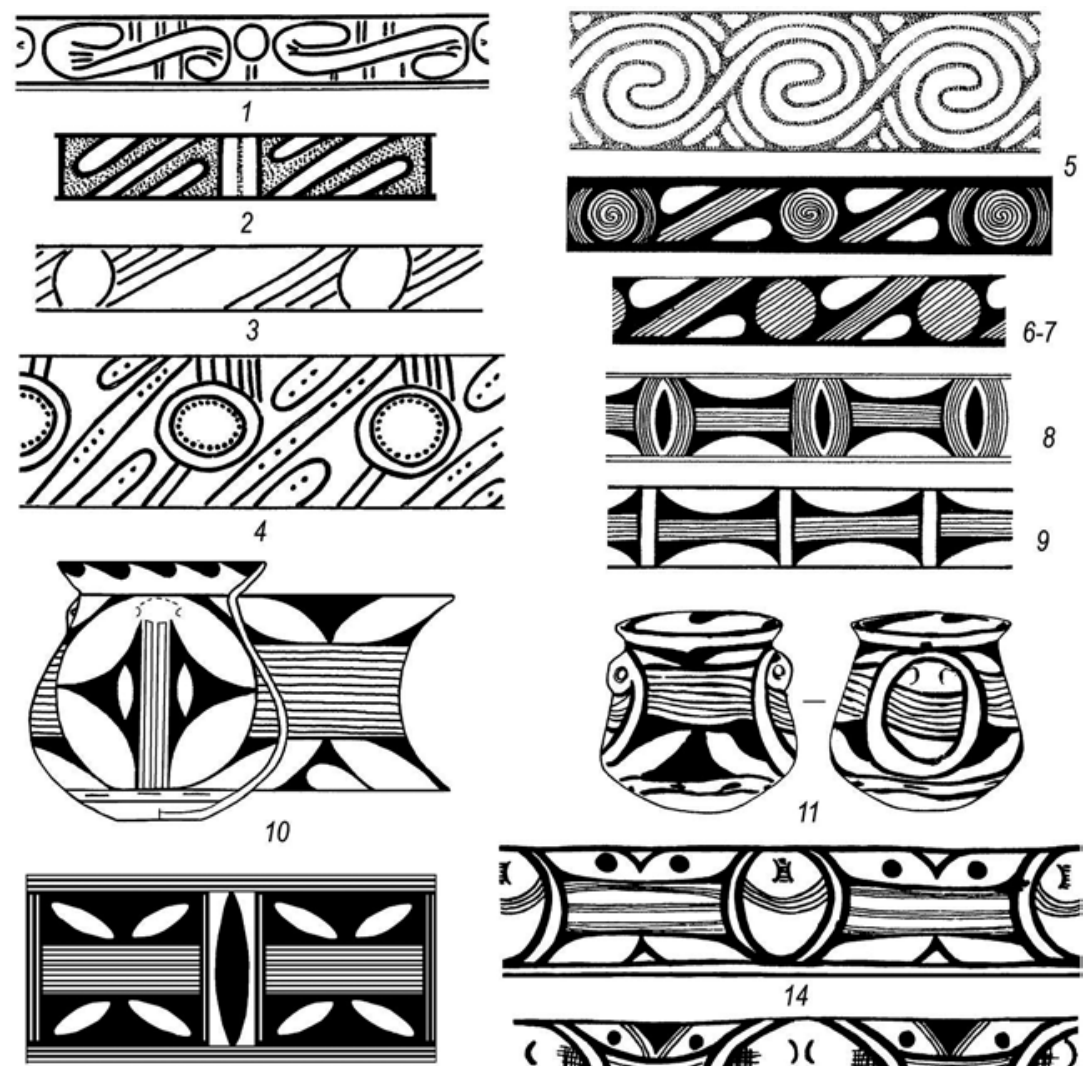

12

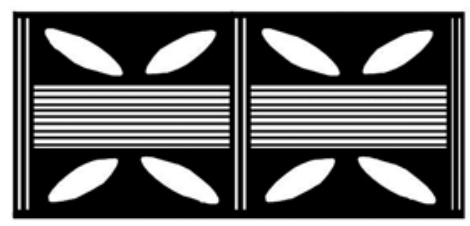

13
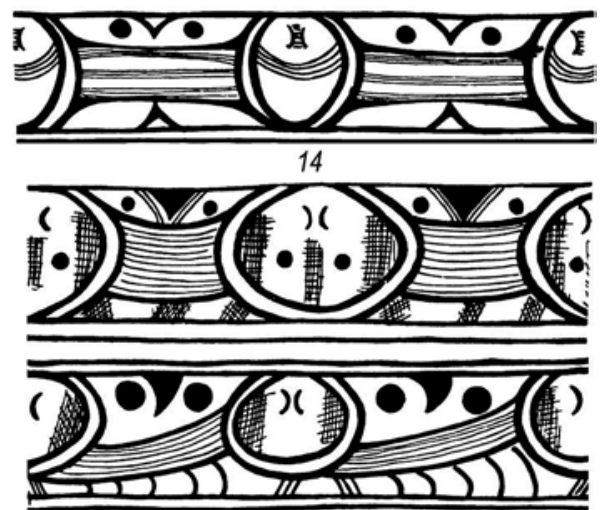

$15-16$

Fig. 1. Development of the face motif in the Tripolye ornamentation: 1-4 - the panelling mode formed in spirals by the differentiation of helical patterns and the vertical division of the ornamented area;

(1 - Truşeşti, Cucuteni A period, see M. Petrescu-Dimbovița; 2 - Hăbăşeşti, Cucuteni A period, see VI. Dumitrescu; 3 - Tirpeşti, Precucuteni culture, see S. Marinescu-Bîlcu; 4 - Cucuneştii Vechi, Cucuteni A period); 5-9 - helixes evolving thorough tangents into sequential rectangular elements (5, 8 - Dragănăşti-valea Ungureanului, Cucuteni A-B period; 6-7 - Taian-dealul Fintinilor, Cucuteni A-B period, see VI. Dumitrescu; 9 - Dragănăşti-Curtea Boiaresc, Cucuteni A-B period); 10-13 - examples of early variants of the face motif; the use of dots related to marking and 'technical' ornamentation in the context of the standardization of pottery production (14 - Petreny, 15-16 - Tomashovka, Tripolye $\mathrm{Cl}-$ Cucuteni 
of them agreed that 'interpretation of images created by tribes without written language is impossible without analysis of ethnographic materials' (Melnichuk 1990, 40). Those materials were taken from the myths of China, Australian Aborigines, South American Indians, etc. What was their relevance to the ideology of early farmers who had inhabited Europe in the $5^{\text {th }}$ and the 4 th millennia BC? The authors carefully bypassed the question, acting on the assumption that early Europeans might have had the same beliefs.

Their interpretations were mostly based on the perceived likeness of the motifs to images selected randomly from a variety of historical or ethnographic materials. Ariel Golan's book Myth and Symbol: Symbolism in Prehistoric Religions (Golan 1991) is a striking example, as it takes symbols used in different cultures out of their native contexts and orders them on the principle of their formal similarity. In cultural anthropology and ethnology, that 'illustrative rather than ... comparative method, almost what psychologists used to call the anecdotal method', with numerous 'miscellaneous examples ... brought together to illustrate some general idea and in support of the author's thesis about that idea" (EvansPritchard 1965,10 ) was abandoned in the 1920 s or 1930 . In the study of prehistory and in archaeology, however, it survived until the 1990s.

Interpretations based only on analogies are ineffective in analysing the variability of the patterns within particular ceramic assemblages as well as their evolution in time, reflected by typological series. For example, so-called face motif in the Tripolye painted ornamentation has persistently been interpreted as representation of an anthropomorphic or zoomorphic face (Tkachuk 1991, 57). In fact, the motif resulted from an evolving spiral pattern: its division with vertical metopes (Fig. 1:1-4, 5-7), the transformation of connecting elements into main ones (Fig. 1:8-9, 10-13) and, sometimes, the conversion of handles into 'technical' elements painted as points that also function as markers (Fig. 1:14-16). Similarly, discussion on snakes or dragons painted on the Tripolye vessels (Zbenovich 1991; Rindiuk 1994) is meaningless and unsupported by serious typological research. Precise statements about the meaning of the ornamentation are simply impossible because of the schematization and decorative stylization of the patterns, their variability and, possibly, polysemous nature.

According to ethnographic information, the way ornamental patterns are interpreted by their makers themselves is not uniform and unchanging. For example, research carried out in the 1920s (Bunzel 1972) showed that the same decorative motifs were given different names by pottery makers in New Mexico and by pueblo Indians in Arizona. Therefore, the terms 'snake' or 'face motive', when referring to unrealistic and recognizable ornamental motifs on pottery produced by the Tripolye-Cucuteni or any other early agricultural culture, can only be used as conventional names of the patterns. 


\section{IS IT POSSIBLE TO 'READ' ORNAMENTAL PATTERNS?}

In the past decades, a new trend has evolved on the basis of Gimbutas' interpretations. It states that the ornamental patterns should be viewed as a sign system, its elements and motifs being signs or symbols. For example, some elements of pottery or figurine ornamentation in materials of the Vinča culture, which was contemporaneous with the early Tripolye-Cucuteni culture in the Middle Danube basin, have often been considered as signs of a 'Danube or Old European script'. The interpretation has been related to clay tablets inscribed with mysterious symbols found in Tărtăria, a Vinča settlement, in 1961. Researchers have attempted to read the Tărtăria tablets as an ideographic script analogous to the pre-dynastic Mesopotamian tablets or the ideograms of the Indus valley civilization. Without entering into discussion on the authenticity of the find and its archaeological context (Merlini, Lazarovici 2008 etc.), I need to note that the Tărtăria tablets have remained the only find of that kind in south-eastern Europe since their discovery. Other items are different in nature: amulets and tablets with crude ornamentation, isolated signs which may have been elements of larger motifs, or marks looking like random touches (see Lazarovici G., Lazarovici C.-M., Merlini 2011, 190-208, fig. VIIC.40-71; Luca 2014, 105-106, fig. 30, 39; Luca, Mărcuți 2015). Generally, the items have no groupings of 'ideograms' arranged in rows resembling a readable text like those in the Tărtăria tablets. Despite this, there have been numerous attempts at cataloguing the single marks recorded on anthropomorphic figurines and such clay finds as spindle whorls, weights for looms, 'altars' or vessels, interpreted as the Vinča proto-script (Winn 1981; Merlini 2006; 2007; 2014; Lazarovici 2003 etc.).

The presence of signs on the ceramics and sculpture cannot be denied; however, closer examination shows that many of them are elements of larger ornamental patterns, schematic representation of items of clothing (on figurines) or a result of careless decorative work. As Pavel Kozhin noted, 'script is a plausible thesis only when there are marked groups of signs in various combinations, with distinguishable logical-grammatical or compositional-graphical interrelations which make it possible to consider the arrangements of signs as texts amenable to monosemic comprehensive interpretation" (Kozhin 2014, 116-117).

In a similar way, interpreting the ornamental pattern on pottery as texts composed of ideograms and searching for their semantics based on a pictographic system have resulted in a structural-semiotic approach in the study of the Tripolye ornamentation. Some researchers have tried to read those 'texts' by identifying and systematizing stable combinations of signs superimposed on the main ornamental scheme (Tkachuk 1993; 2004; 2005; Tkachuk, Melnik 2000), considering the signs as elements of the text. The results of those attempts have been arbitrary and subjective. The apparently abstract shape of the motifs 
has been explained, in lack of other arguments, with altered states of consciousness brought about by hallucinogens used presumably by the pottery makers (Tkachuk 2002).

However, a number of questions may be raised about the assumptions underlying those interpretations. Should we interpret the whole pattern as a single sign or symbol or rather as a text involving a set of signs? Are all marks to be regarded as signs in that text, or may at least some of them be viewed as transformed elements of the decorative motif?

Analysis of ornamental patterns can be based on close examination of typological series and sequence application of particular motifs. Examination of that kind shows that ordinary signs (circles, semi-circles, dots) are mostly elements of 'technical ornamentation': primarily, derivatives of handles (Fig. 2:8, 9) or dots and lines marking the composition (Kozhin 1981, 135-136; 1991, 130; Palaguta 2009). It is doubtful whether they have special meaning. If their prehistoric makers formed any interpretation of their significance, it was probably random and sometimes irrespective of the shape of the elements themselves, and it could be different not only in each culture, but also in particular groups within the same cultural tradition.

The above critique of the most common approaches to prehistoric ornamental patterns (see also Palaguta 2008) leads to the question if, in principle, unambiguous interpretation of those patterns and identification of their semantics are possible at all. The ornamentation no doubt had a meaning. There are numerous ethnographic records of the extensive and varied terminology used by pottery makers to denote different arrangements or individual decorative elements (see e.g. Peshchereva 1959, 78-108, 109-115). However, ethnographic observations usually provide only one-stage information and cannot determine what the original meaning of the ornamental patterns was even several generations earlier. Research on pueblo Indians' pottery production has shown that the same elements of design were given different names even by potters living in the same village. Among the Zuni, for example, 'cirrus clouds' easily became the 'Milky Way', a 'spider web' turned into 'yucca suds' or 'feathers', while among the Acoma people, the 'leaf and steps' pattern became a 'star with clouds' (Bunzel 1972, 92-128).

Pottery makers' interpretations are thus often individual and related only superficially to the form of the ornamentation. Tajik fabrics may be mentioned as another example: in various villages, the same ornamental motifs were called 'wolf's paw', 'horned dragon' or 'the pattern from printed cotton' of machine-made manufacturing (Andrev 1928). Interpretation of the ornamental patterns and related imagery may have changed in prehistoric cultures in a similar fashion, especially in the periods of rapid transformation and migration.

The Tripolye-Cucuteni culture lasted nearly one and a half millennia. In that period, the ornamentation changed, forming not only chronological, but also local varieties. Obviously, the names and meanings changed as well. The question arises, therefore, whether ornamental patterns can or should be analysed systematically at all. 


\section{PREHISTORIC ORNAMENTATION: PROSPECTS FOR RESEARCH}

In plastic arts no less than in music, rhythmic alternation and harmonious combination of elements and motifs are one of the main goals to be achieved. In art, nonverbal factors play an important role in subconscious perception of statics, dynamics, rhythm and sustainability (see Pasto 1964). Thus, the pattern is not identical to the image; it seems a special kind of art which, as noted by H.-G. Gadamer, is often devoid of conceptual content (Gadamer 1986). If the artist wants to transcend that meaning of the ornament, they fit the image into its context, as evidenced in the Tripolye-Cucuteni material (Fig. 2:10). Images like those were popular in the late Tripolye-Cucuteni culture (Movsha 1991; Zbenovich 1998; Țerna 2007; Palaguta 2012). Ornamental patterns had an organizing role, imposing rhythm and order, and thus contributing to the overall shape of the item. Repeated technical elements and stylized images may also have been the basis of a rhythmic system in ornamentation.

Ethnographic research into pottery making suggests that ancient potters seldom created complex classifications of patterns, considering instead only basic elements. Supplementary elements were added to the design within individual variations. Interesting examples of that approach to ornamentation have been presented by M. Hardin (Hardin 1983, 77-78, 85-87). When decorating their pottery, Mexican craftsmen used traditional sets of ornamental motifs, but only the entire layout indicated the type of vessel in the author's own classification. The particular form of vessel could not be assessed before the decorative process was completed (Hardin 1979, 77-78, 85-87, 95-98; 1983, 95-98). Moreover, the patterns were applied by the desimmetrization method, i.e. successive division of the area intended for ornamentation (Greenberg 1975; Jablan 1995; 2002), rather than by basing the additional arrangement on the dominant motifs or by chaining the ornamental elements in the way texts are constructed. The principle of forming the patterns was thus entirely different from that typical of a text.

The rhythm and repetition of ornamental motifs, their stylization and schematization limit significantly the possibility of conveying information. Therefore, ornamentation cannot be equated with a text composed of pictographs or hieroglyphics, and ornamental elements cannot be equated with signs of a text, although pictographs and hieroglyphics may include, as painted ornamentation does, abstract, figurative or rhythm-forming elements (Kozhin 2007, 102-103, 119-120).

Ornamental patterns do have a certain meaning. The meaning, however, is conveyed by the pattern as a whole, and not by its mobile elements which can be modified in accordance with the shape and surface of the ornamented area to achieve the maximum decorative effect. Essentially, ornamental patterns help to identify things in visual interpretation of the nature of objects or situations and they help to define the category of an object. They also indicate the position of the object in the classification of the material world typical of a particular culture. Moreover, ornamentation emphasizes or increases the functionality 

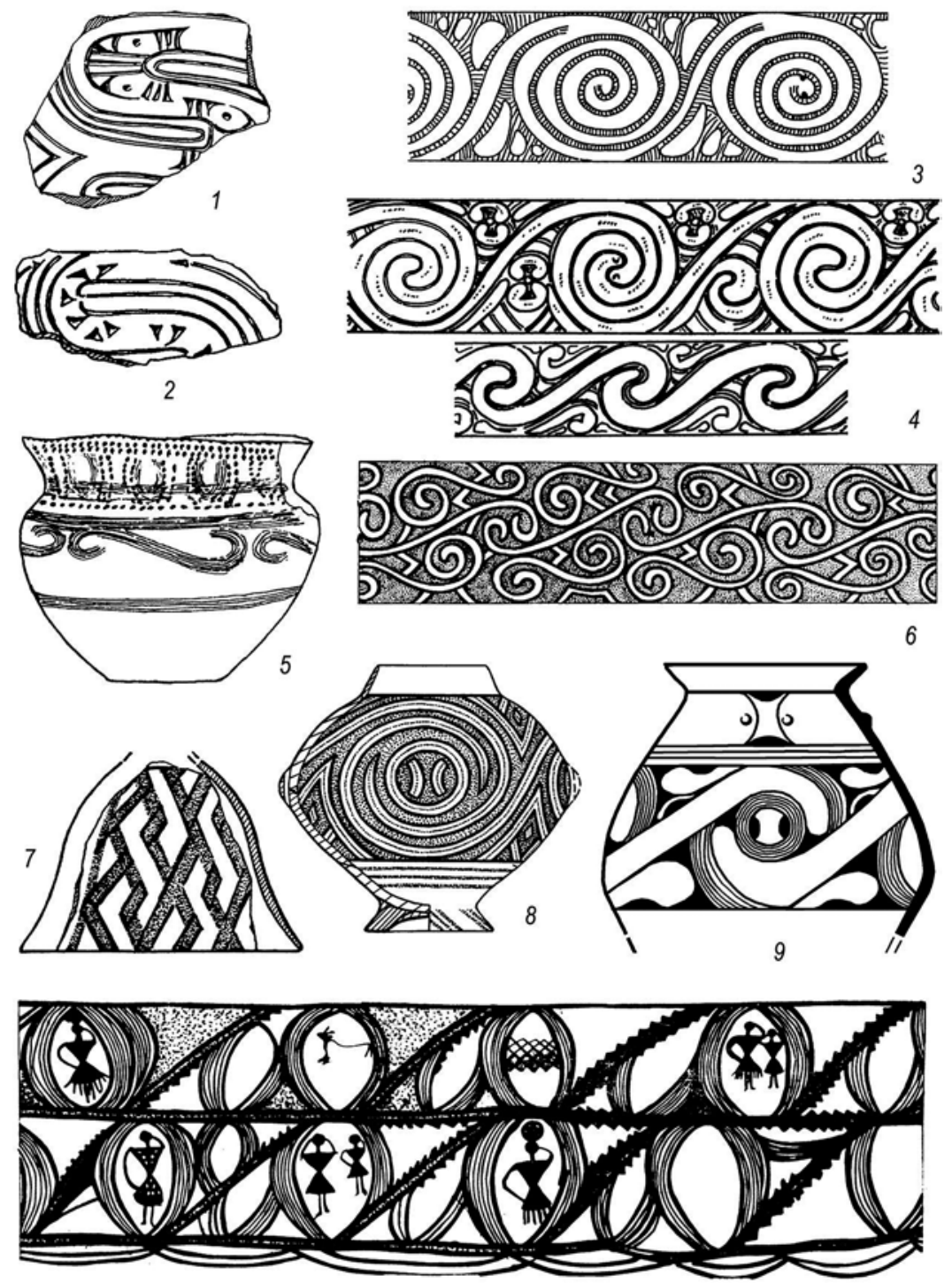

10

Fig. 2. Ornamentation in the Tripolye-Cucuteni culture: 1-2 - snake motifs, Floreşti, early Tripolye Precucuteni; 3 - a variant of the positive snake helical pattern, Lenkovtsy, early Tripolye - Precucuteni; 4 - transformation of the snake motifs into helical patterns through reversal, Truşeşti, Cucuteni A period, see M. Petrescu-Dimbovița; 5 - a Tripolye pattern made by a member of another ceramic tradition: a positive S-helix on shell-tempered pottery related to the Steppe Eneolithic cultures, Drăguşeni, Cucuteni A period, see A. Crişmaru; 6 - a helical pattern transformed through its reversal, Zhura, Cucuteni A period; 7 - an example of the decorative reproduction of wattle, Drutsa I, Cucuteni A period; 8 - transformation of handles into decorative elements ('technical' ornamentation), Drutsa I, Cucuteni A period; 9 - transformation of handles into decorative elements, Bernashovka, Tripolye Cl period, see T.M. Tkachuk; 10 - an example of pictures inscribed into ornamentation, Brinzeni III, Tripolye Cl period, see V. Marchevici 
of an item. As Rudolf Arnheim noted, 'an ornament, as we can now define it, presents an easy order, undisturbed by the vicissitudes of life. Such a view is quite justified when the pattern is not intended as an independent whole but as a mere component of a larger context, in which an easy harmony has a legitimate place' (Arnheim 1974, 145-152).

In cross-cultural communication, therefore, patterns rather than their elements refer to things indicative of a particular culture or act as signs in social interactions within the same population group or in contacts between members of different groups. It should also be noted that a single assemblage includes not only pottery, but also architectural decorative elements and ornamentation of clothing, home accessories or the human body. Ornamentation, together with the shape of the item, is thus an integral part of the language of things' which plays an important role in cultural communication. As a sign, it is considered at the intracultural and the intercultural levels, where it most often involves a set of patterns with similar motifs that are characteristic of a given ethnic or social group and reflect its hierarchy (Summers 2003, 98-101). This can be illustrated with many ethnographic examples (Braithwaite 1982, 80-88).

Comprehensive analysis of prehistoric ornamentation covers the possibility that abstract figures were interpreted by their makers by free association and that they referred to certain myths, situations, actions or things. Nevertheless, we can only guess at those meanings of the patterns, as they were the most changeable. The Tripolye ornamentation definitely changed in time. The snake motif typical of the early Tripolye patterns is quite clearly composed of two snakes (Fig. 2:1-2, 3). Its meaning may have been related to self-identification of members of the Tripolye culture; the motif could also have been a sign alluding to a certain text, but it has not revealed its meaning, as no decorative element can be expected to do. However, the snake motif was modified in the subsequent phases of TripolyeCucuteni culture, which resulted in a reversal of the pattern: the background became more pronounced than the figures themselves (Fig. 2:4, 6). The modification is reminiscent of the pattern of background spirals made with different technique in other ceramic traditions (Fig. 2:5). The question is whether the original meaning of the snake motif survived that transformation.

Despite the limited nature of the interpretation, which often relies on indirect inferences, the patterns provide data on the dynamics of cultural change, contacts between communities, as well as on numeration, symmetry and geometry of space (see Shepard 1948). Analysis of a series of patterns suggests how the pottery makers changed their approach across generations, the motifs lost their original meaning and the images turned into abstract decorative elements. The rate of the changes may have been different; some patterns retained their composition for centuries, while other ones transformed across a few generations (Nikolov, Karastoianova 2003; see also Palaguta 1999; 2007, 32, 61-63).

Without entering into ungrounded conjectures about the interpretation of the patterns, we can determine the main directions in further research, which lie not so much in the field of semantics as in cultural anthropology and art history, since the style of orna- 
mentation reveals characteristics of visual perception of form and space. It is important, therefore, to analyse the patterns in the context of the entire archaeological culture combining pottery, sculpture, forms of dwellings and architectural elements and to consider the possible impact of the patterns and surface texture of items made of unpreserved organic material on the 'technical' ornaments (Fig. 2:7) (Palaguta 2009). When analysing the patterns on pottery, one should not only try to reconstruct correctly the typological series, but also to identify the distribution of particular variations of ornamental elements and compositions within a single assemblage. In this field, noteworthy comparison of the sets of ornamental elements within separate dwellings has been carried out by Taras M. Tkachuk on the basis of materials recovered from the giant Tripolye-Cucuteni settlement Maydanetskoe (Tkachuk, Melnik 2000, 152-153, 205, fig. 18).

Changes in decorative motifs mark the moments of cultural transformation. Obviously, the reversed patterns, the emphasis shifted from figures themselves to their background and additional elements converted into dominant ones suggest not only that new 'fashions' arose in ornamentation, but also that the elements lost their former meaning and the new generation of pottery makers saw them quite differently from the previous one (Palaguta 2007, 58-63; 2009a). The same conclusions concern the decline of the patterns and their arrangements. In traditional cultures, such displacements usually indicate significant changes both in the social structure and the ethnic composition of the population, with new members being unable to fit the ornamentation into the earlier tradition. Thus, the ornamentation helps to distinguish cultural and ethnic groups, showing both differences between them and the intensity of their interactions. Such inferences have repeatedly been drawn in ethnographic research on pottery (see e.g. Friedrih 1970).

The presence of 'elite' ware points to emergent social stratification. The uniformity of the motifs, on one hand, reflected the initial stages of settlement, as illustrated by the Starčevo - Körös - Criş culture and the early Linear Band ceramics; on the other, it might have been linked to mass production of pottery represented by the Balkan Eneolithic cultures, including the late Tripolye-Cucuteni culture. The process corresponded with social transformation. The general tendency for ornamentation to decline during the transition to mass production in the period when early states were formed has been noted by many researchers (Rice 1981). The study of pottery standardization in the Tripolye communities seems promising, too, due to the development of giant settlements with thousands inhabitants in the later phases of that culture.

In conclusion, I would like to note that despite the critical tone of many statements, my paper is intended to show a possible new focus in research on prehistoric ornamental patterns. Instead of searching for possible meanings of the motifs the study may now centre around reconstructing the role of the ornamentation in the cultural development. 


\section{References}

Andreyev M. S. 1928. Ornament gornykh Tadzhikov verkhovev Amu-Darii i Kirgizov Pamira. Tashkent: Obshchestvo dla izuchenia Tadzhikistana i iranskikh narodnostey za ego predelami. Arnheim R. 1974. Art and Visual Perception: A Psychology of the Creative Eye. Berkeley and Los Angeles: University of California Press.

Bailey D. W. 1994. Reading prehistoric figurines as individuals. World Archaeology 25(3), 321-331.

Bogaevsky B. L. 1931. Rakoviny v raspisnoy keramike Kitaia, Krita i Tripolia (= Izvestia Gosudarstvennoy Akademii istorii materialnoy kultury 6(8-9)). Leningrad.

Bolsunovsky K. V. 1905. Simvol zmia v „Tripolskoy kulture”. Mifologicheskiy etiud (Referat, prigotovlennyi k chteniiu vo vremia XIII Arkheologicheskogo sezda v Ekaterinoclave v avguste 1905). Kiev: Tipo-litografiia N. A. Giricha.

Bolsunovsky K. V. 1908. Simvolika epokhi neolita, s tablitsey risunkov. Kiev: Progress.

Braithwaite M. 1982. Decoration as ritual symbol: a theoretical proposal and an ethnographic study in southern Sudan. In I. Hodder (ed.), Symbolic and structural archaeology (= New Directions in Archaeology). Cambridge: Cambridge University Press, 80-88.

Bunzel R. L. 1972. The Pueblo potter: a study of creative imagination in primitive art. New York: Dover Publications.

Burdo N. B. 1999. Zmiia v rannotripilckikh ornamentakh ta mifakh. In Kratkie soobshchenia Odesskogo arkheologicheskogo obshchestva. Odessa: Odesskiy arkheologicheskiy muzey, 23-28.

Chapman J. C. 1999. The Origins of Warfare in the Prehistory of Central and Eastern Europe. In J. Carman and A. F. Harding (eds.), Ancient Warfare: Archaeological Perspectives. Stroud: Sutton Publishing, 101-142.

Chikalenko L. 1926. Naris rozvitku ukraenskoy neolitichnoy malovanoy keramiki 2. Bilche Zolote. In Tripilska kultura na Ukraieni 1. Kiev, 113-119.

Čikalenko L. 1927. Studie o vývoji ukrajinské neolithické malované keramiky. I. Sidliště Petreni v Besarabii. Obzor praehistorica 5-6, 21-29.

Dintses L. A. 1929. Procherchenniy tripolskiy ornament kultury A (= Sbornik biuro po delam aspirantov GAIMK 1). Leningrad, 15-29.

Evans-Pritchard E. E. 1965. Theories of Primitive Religion. Oxford: Oxford University Press.

Friedrich M. H. 1970. Design structure and social interaction: archaeological implications of an ethnographic analysis. American Antiquity 35(3), 332-343.

Gadamer H.-G. 1986. The Relevance of the Beautiful and Other Essays. Cambridge: Cambridge University Press.

Gimbutas M. 1974. The Gods and Goddesses of Old Europe: 70oo to 350o BC. Myth, Legends and Cult Images (= Hermeneutics, studies in the history of religions 4). Berkeley and Los Angeles: University of California Press.

Golan A. 1991. Myth and Symbol: Symbolism in Prehistoric Religions. Jerusalem: Schoen Books.

Greenberg L. J. 1975. Art as a structural system: a study of Hopi pottery designs. Studies in the Anthropology of Visual Communications 2(1), 33-50. 
Hardin M. A. 1979. The Cognitive Basis of Productivity in a Decorative Art Style: Implications of an Ethnographic Study for Archaeologists' Taxonomies. In C. Kramer (ed.), Ethnoarchaeology: Implications of Ethnography for Archaeology. New York: Columbia University Press, 75-101.

Hardin M. A. 1983. The structure of Tarascan pottery painting. In D. K. Washburn (ed.), Structure and Cognition in Art (= New Directions in Archaeology). Cambridge: Cambridge University Press, 8-24.

Hutton R. 1997. The Neolithic great goddess: a study in modern tradition. Antiquity 71(271), 91-99.

Jablan S. V. 1995. Theory of Symmetry and Ornament. Belgrade: Mathematical Institute.

Jablan S. V. 2002. Symmetry, Ornament and Modularity (= Series on Knots and Everything 30). Hackensack, NJ: World Scientific Publishing.

Kandyba O. 1935. Die forlaufende Spirale in der bandkeramischen Ornamentik. Archiv für Anthropologie 23, 266-308.

Kandyba O. 1936. S-spiral in the Decoration of the Dniestro-Danubian Neolithic Pottery. American Journal of Archaeology 40(2), 228-246.

Kleyn L. S. 1993. Fenomen sovetckoy arkheologii. Sankt-Petersburg: Farn.

Kleyn L. S. 2000. Arkheologiia v sedle. (Kosinna c rasstoiania v 70 let). Stratum plus 4, 88-140.

Kozhin P. M. 1981. Znachenie ornamentatsii keramiki i bronzovykh izdeliy Severnogo Kitaia v epokhi neolita i bronzy dlia issledovaniy etnogeneza. In M. V. Kriukov, M. V. Sofronov and N. N. Cheboksarov (eds.), Etnicheskaia istoriia narodov Vostochnoy i Iugo-Vostochnoy Azii v drevnosti i srednie veka. Moskva: Nauka, 131-161.

Kozhin P. M. 1991. O drevnikh ornamentalnykh sistemakh Evraziy. In Yu. V. Bromley (ed.), Etnoznakovye funktsii kultury. Moskva: Nauka, 129-151.

Kozhin P. M. 2007. Etnokulturnye kontakty naselenïa Evrazii v eneolite - rannem zheleznom veke (paleokulturologia i kolesnyi transport). Vladivostok: Dalnauka.

Kozhin P. M. 2014. Priskhozhdenie i razvitie keramicheskogo proizvodstva i raspisnoy ornamentatsii glinianoy posudy. In Trudy Margianskoy arkheologicheskoy ekspeditsii 5. Issledovaniia Gonur Depe v 2011-2013 g. Moskva: Stary Sad, 112-126.

Krichevskiy E. Yu. 1949. Ornamentaciya glinyanykh sosudov u zemledel'cheskih plemen neoliticheskoy Evropy. Uchenye zapiski LGU 13, 54-110.

Lazarovici G. 2003. Sacred Symbols on Neolithic Cult Objects from the Balkans. In L. Nikolova (ed.), Early Symbolic Systems for Communication in Southeast Europe (= British Archaeological Reports. International Series 1139). Oxford: Archaeopress, 57-64.

Lazarovici G., Lazarovici C.-M. and Merlini M. 2011. Tărtăria and the Sacred Tablets. Cluj-Napoca: Editura Mega.

Lesure R. G. 2011. Interpreting Ancient Figurines. Context, Comparison, and Prehistoric Art. Cambridge: Cambridge University Press.

Linnichenko I. A. and Khvoyka V. V. 1901. Sosudy so znakami - iz nakhodok na ploshchadkakh tripolskoy kultury. Zapiski Odesskogo obshchestva istorii i drevnostey 23, 199-202.

Luca S. A. 2014. Art and Religious Beliefs in the Neolithic and Aeneolithic from Romania. Sibiu: Editura Museului National Brukenthal. 
Luca S. A. and Mărcuți F. 2015. Prehistoric Signs and Symbols from Transylvania (1). "The Secret Tablet” the Neolithic and Aeneolithic Archaeological Settlement from Tărtăria - Gura Luncii (Alba County). Brukenthal. Acta Musei 10(1), 7-16.

Melnichuk I. V. 1990. Izobrazhenie zmei Tripole. In V. A. Dergachev (ed.) Arkheologicheskie issledovaniia molodykh uchenykh Moldavii. Kishinev: Shtnintsa, 39-46.

Merlini M. 2006. The Gradešnica script revisited. Acta Terrae Septemcastrensis 5, 25-77.

Merlini M. 2007. A semiotic matrix to distinguish between decorations and signs of writing employed by the Danube Civilization. Acta Terrae Septemcastrensis 6, 73-130.

Merlini M. 2014. The sacred cryptograms from Tărtăria: unique or widespread signs? Putting the asserted literate content of the tablets under scrutiny. In J. Marler (ed.) Fifty Years of Tărtăria Excavations. Festschrift in Honor of Gheorghe Lazarovici on the occasion of his $73^{\text {rd }}$ Birthday. Suceava, Sebastopol: Editura Lidana, Institute of Archaeomythology, 73-119.

Merlini M. and Lazarovici G. 2008. Settling discovery circumstances, dating and utilization of the Tărtăria tablets. Acta Terrae Septemcastrensis 7, 111-196.

Meskell L. M. 1995. Goddesses, Gimbutas and "New Age" archaeology. Antiquity 69(262), 74-86.

Movsha T. G. 1991. Antropomorfnye siuzhety na keramike kultur tripolsko-kukutenskoy obshchnosti. In V. F. Gening (ed.), Dukhovnaia kultura drevnikh obshchestv na territorii Ukrainy. Kiev: Naukova dumka, 34-47.

Nikolov V. and Karastoianova D. 2003. Risuvanata ornamentatsiia kato sistema za komunikatsiia mezhdu pokoleniiata (po materiali ot ranno- i srednonelitniia plast na tel Kazanlk). Arkheologia 44(2), 5-14.

Palaguta I. V. 1999. Problemy izucheniia spiralnykh ornamentov tripolskoy keramiki. Stratum plus 2, 148-159.

Palaguta I. 2007. Tripolye Culture during the Beginning of the Middle Period (BI): The relative chronology and local grouping of sites (= British Archaeological Reports. International Series 1666). Oxford: Archaeopress.

Palaguta I. V. 2008. Mify i realnoct v interpretatsii ornamentov drevnikh zemledeltsev. In Dialog kultur i partnerstwo tsivilizatsiy: VIII Mezhdunarodnye Likhachevskie nauchnye chteniia. Sankt-Peterburg: SPGUP, 216-217.

Palaguta I. 2009. "Technical decoration" of the Tripolye Ceramics. Archaeology, Ethnology and Anthropology of Eurasia 37(2), 85-91.

Palaguta I. V. 2009a. Iavlenie obratimosti i osnovnye napravleniia razvitiia kompozitsiy ornamentov tripolsko-kukutenskoy keramiki. Materialy 9-11 zasedaniy nauchno-metodicheskogo seminara „Tverskaia zemlia i sopredelnye territorii $v$ drevnosti”. Tverskoy arkheologicheskiy sbornik 7. Tver: Triada, 411-418.

Palaguta I. V. 2012. Mir iskusstva drevnikh zemledeltsev Evropy. Kultury balkano-karpatskogo kruga $v$ VII-III tys. do n.e. Sankt-Petersburg: Aleteia.

Pasto T. 1964. The Space-Frame Experience in Art. New York: Barnes.

Peshchereva E. M. 1959. Goncharnoe proizvodstvo Sredney Azii (= Trudy Instituta etnografii im. N. N. Miklukho-Maklaia 42). Moskva, Leningrad: Nauka. 
Rice P. M. 1981. Evolution of specialized pottery production: A trial model. Current Anthropology 22(3), 219-240.

Rindiuk N. V. 1994. Dejaki pitannia ideologii dawnozemlepobskikh plemen. Arkheologia 1, 145-147.

Rybakov B. A. 1964. Semantika tripolskogo ornamenta. In Tezisy dokladov na zasedaniiakh, posviashchennykh itogam polevykh issledovaniy $1963 \mathrm{~g}$. Moskva: AN SSSR, 23-24.

Rybakov B. A. 1981. Iazychestvo drevnikh slavian. Moskva: Nauka.

Schmidt H. 1924. Prähistorisches aus Ostasiens. Zeitschrift für Ethnologie 5/6, 133-157.

Shepard A. O. 1948. The symmetry of abstract design with special reference to ceramic decoration (= Contributions to American Anthropology and History 9(47). Publication 574). Washington D.C.: Carnegie Institution of Washington.

Summers D. 2003. Real Spaces. World Art History and the Rise of Western modernism. London and New York: Phaidon Press.

Telegin D. Ya. 1994. Obraz zmeelikoy bogini v Tripole. In Drevneishie obshchnosti zemledeltsev i skotovodov Severnogo Prichernomoria Vtys. do n.e. - Vv.n.e. Materialy Mezhdunarodnoy arkheologicheskoy konferentsii 10-14 oktiabria $1994 \mathrm{~g}$. Tiraspol: Nauchno-issledovatelskaia laboratoria „Arkheologia”, 73-74.

Țerna S. 2007. Considerații preliminare privind evoluția decorului antropomorf pictat de pe ceramica culturii Cucuteni-Tripolje. Peuce 5, 33-42.

Tkachuk T. M. 1991. Lichiny v rospisi keramiki kultury Tripole-Kukuteni. In V. F. Gening (ed.), Dukhovnaia kultura drevnikh obshchestv na territorii Ukrainy. Kiev: Naukova dumka, 47-59.

Tkachuk T. M. 1993. Znakova sistema Tripilskoy kultury. Arkheologia 3, 91-100.

Tkachuk T. M. 2002. Tripilskiy ornament ta zmineni stani cvidomosti. Galichina 8. Ivano-Frankivck, 13-22.

Tkachuk T. M. 2004. Znakovi sistemi tripilskoy kultury. In M. Yu. Videiko (ed.), Entsiklopediia tripilskoi tsivilizatsii: $v$ 2-kh 1. Kyiv: Ukrpoligrafmedia 433-471.

Tkachuk T. M. 2005. Znakovi sistemi Tripilsko-Kukutenckoy spilnosti (malovaniy posud etapiv VIISII/ $\gamma I I)$ 1-2, Vinnitsia: Nova Kniga.

Tkachuk T. M. and Melnik Ya. G. 200o. Semiotichniy analiz tripilsko-kukutenckikh znakovikh system (malovaniy posud). Ivano-Frankivck: Play.

Tsvek E. V. 2004. Nekotorye ornamantalnye kompozitsii na keramike vostochnotripolskoy kultury. In Izobrazitelnye pamiatniki: stil, epokha, kompozitsii. Material tematicheskoy nauchnoy konferentsii. Cankt-Peterburg: SPBGU, 102-105.

Winn Sh. M. M. 1981. Pre-writing in Southeastern Europe: the sign system of the Vinča culture, ca. 400 B.C. Calgary: Western Publishers.

Zbenovich V. G. 1998. Zoomorfnye motivy v rospisi keramiki kultury Tripole-Kukuteni. Arkheologia 4, 64-78.

Zbenovich V. G. 1991. Drakon v izobrazitelnoy traditsii kultury Kukuteni-Tripole. In V. F. Gening (ed.), Dukhovnaia kultura drevnikh obshchectv na territorii Ukrainy. Kiev: Naukova dumka, 20-34. 